This is a post-print version of the article originally published as Fricke, H. (2017). The rise of clausefinal negation in Flores-Lembata, Eastern Indonesia. Linguistics in the Netherlands, 34(1), 47-62. DOI: https://doi.org/10.1075/avt.34.04fri

\title{
The rise of clause-final negation in Flores-Lembata, Eastern Indonesia
}

\author{
June 26, 2017
}

\begin{abstract}
The Austronesian languages of Flores-Lembata in eastern Indonesia show all three stages of a Jespersen Cycle: some have a negator in pre-predicate position, others in clause-final position, and yet others have embracing double negation. In the article the various negation patterns in the Flores-Lembata languages are described using a sample of nine closely related languages of the region. It examines not only the negative constructions but also the etymology of the negators used, showing historical connections between some of the languages, as well as independent developments in others. On the basis of cross-linguistic evidence and taking into account the non-Austronesian (Papuan) structures found in these Flores-Lembata languages, it is argued that the clause-final negation in several of these languages was caused by contact with speakers of Papuan languages during an earlier stage.

Keywords: Austronesian languages, contact-induced grammaticalization, Jespersen Cycle, clause-final negation, Papuan languages
\end{abstract}

\section{Introduction}

This article discusses patterns of declarative sentence negation in Flores-Lembata languages, a group of Austronesian languages located in the eastern part of Indonesia. The Flores-Lembata languages are located on the island of Flores and several smaller islands adjacent to Flores in the Indonesian province Nusa Tenggara Timur displayed in Figure 1. 


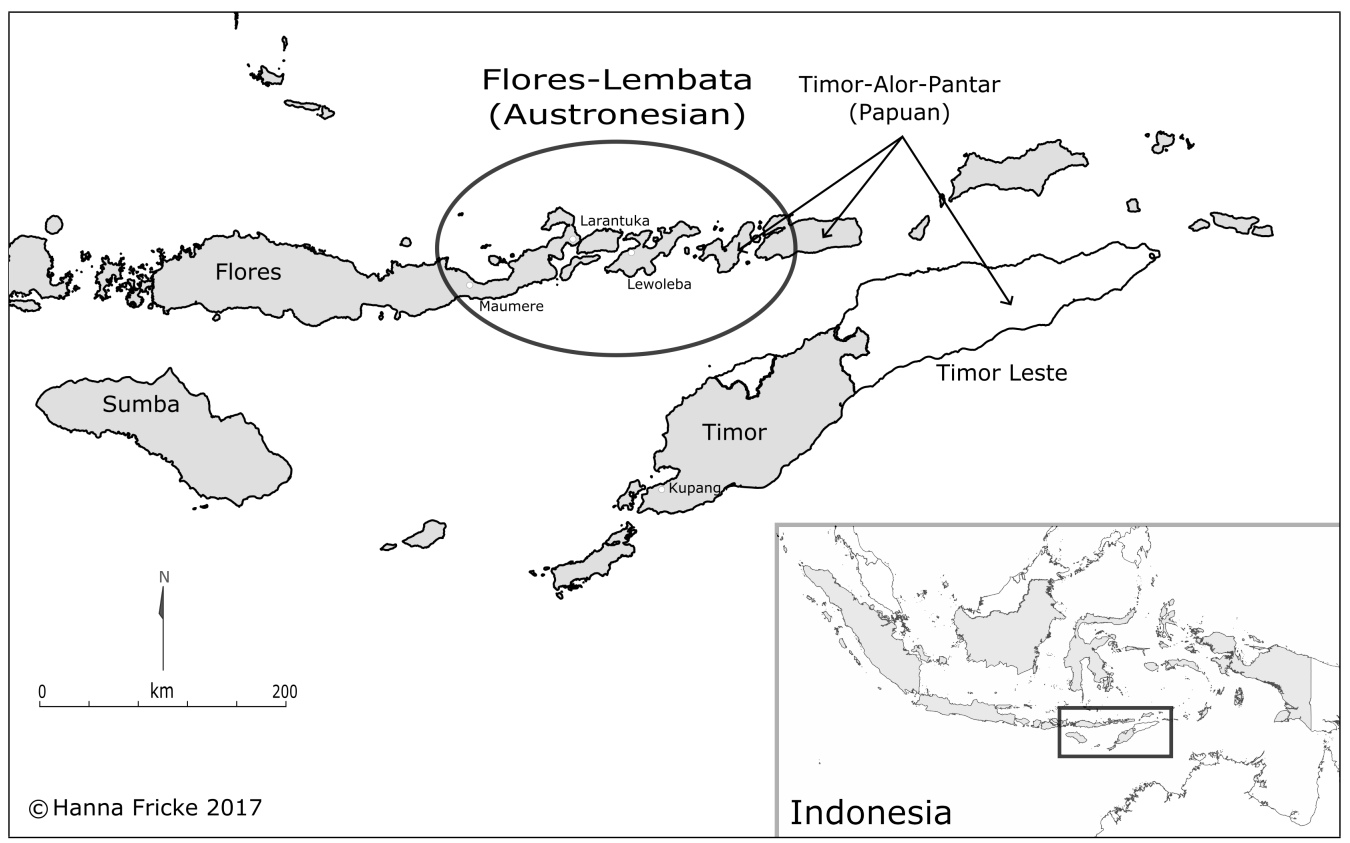

Figure 1: The locations of Flores-Lembata languages and Timor-Alor-Pantar languages in the Indonesian province Nusa Tenggara Timur.

Flores-Lembata languages belong to the Malayo-Polynesian subgroup of the Austronesian family. Towards the east of the Flores-Lembata languages, on the islands of Alor and Pantar, Papuan languages of the Timor-Alor-Pantar family are found (Klamer 2014; Schapper 2014). The term 'Papuan' refers to numerous language families found on and around the island New Guinea. The Papuan languages on the islands of Alor and Pantar are the westernmost instances of Papuan languages found today.

As with 70\% of the world's languages (Vossen 2016:4), Austronesian languages typically show pre-predicate negation marking. However, there is also a considerable number of instances of clause-final negation among Austronesian languages that are located in areas where Austronesian and Papuan languages are located close to each other (Vossen 2016:119-121,202). The Flores-Lembata area is one of them. The pattern of clause-final negation marking in Austronesian languages has been claimed to be of Papuan origin and to have diffused to several Austronesian languages (Reesink 2002:246). This article proposes that several languages of the Austronesian Flores-Lembata group have introduced a pattern of clause-final negation, possibly due to contact with an unknown Papuan language. Clause-final negation has already been identified as a Papuan feature of Lamaholot 
(LH), a dialect chain within Flores-Lembata (Klamer 2012:76). However, the rise of this pattern has not been examined in detail before.

For this article, all published sources that provide data on negation patterns of a Flores-Lembata language are examined. A list of languages and sources following geographic location from west to east is given in Table 1 and displayed in Figure 2.

\begin{tabular}{ll}
\hline Language & Source \\
\hline Sika & Arndt (1931) \\
Hewa & Fricke (2014) \\
LH-Lewotobi & Nagaya (2011) \\
LH-Lewoingu & Nishiyama and Kelen (2007) \\
LH-Solor & Kroon (2016) \\
LH-Lamalera & Keraf (1978) \\
LH-Central Lembata & Fricke (2016) \\
Kedang & Samely (1991) \\
Alorese & Klamer (2011) \\
\hline
\end{tabular}

Table 1: Languages and data sources. $\mathrm{LH}=$ Lamaholot dialect chain.

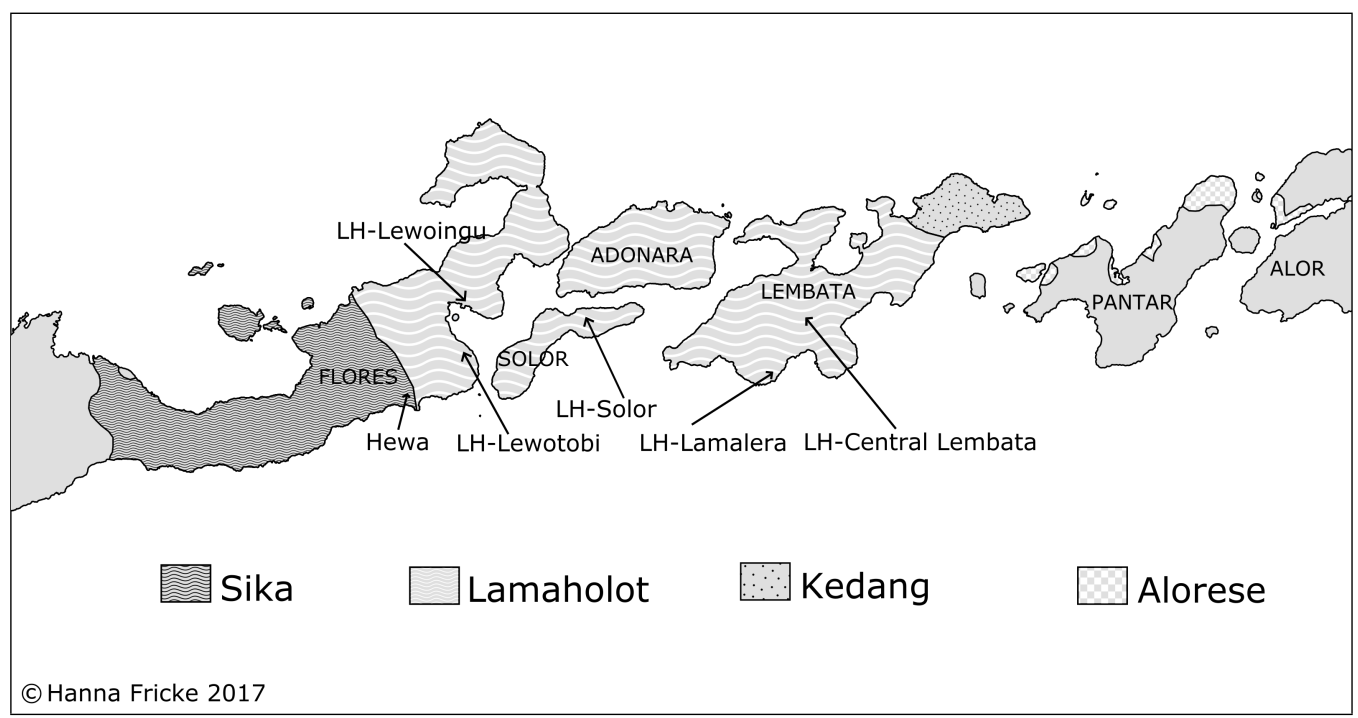

Figure 2: Flores-Lembata languages and locations of data origins.

The language varieties marked with LH in Table 1 and Figure 2 are part of the 
Lamaholot dialect chain (Fricke forthcoming; Keraf 1978) and thus more closely related to each other than to the other varieties in the list. Also, Hewa has been considered a variety of Sika (Keraf 1978:5). Here, I discuss the negation patterns of all varieties, without making claims on the dialect versus language status of these varieties.

This article is structured as follows. Section 2 provides the theoretical background on the model of a Jespersen Cycle to explain the diachronic development of negation in Flores-Lembata. Section 3 presents different negation patterns in the languages of Flores-Lembata. Section 4 discusses etymologies of the negators used in these varieties. The last section discusses the proposal of contact-induced change giving rise to clause-final negation.

\section{Theoretical background: Jespersen Cycle}

A Jespersen Cycle ${ }^{1}$ is a diachronic change from pre-predicate single negation, to double negation, to post-predicate single negation (van der Auwera and Du Mon 2015:412). A well known example is the Romance language French which underwent all three stages of a Jespersen Cycle. Initially, French had a single prepredicate negator $n e$, nowadays standard French uses double negation ne ... pas and colloquial varieties of French already reached the final stage of the Jespersen Cycle by only using the single post-predicate negator pas. The fact that the Jespersen Cycle usually goes from pre-predicate to post-predicate negation and not the other way around can be explained by the univeral tendency for negators to be placed early in the utterance, in particular before the verb (van der Auwera and Du Mon 2015:411).

It has been claimed that in many cases, a Jespersen Cycle starts with the need for emphatic negation (van der Auwera and Du Mon 2015:412). An element is added to the negated sentence to emphasize its negative meaning, over time this emphatic meaning is bleached and the new strategy becomes the neutral negation pattern (van der Auwera 2009:41).

New negators can come from different sources. Cross-linguistically common

\footnotetext{
${ }^{1}$ The term Jespersen Cycle was coined by Dahl (1979:88) who named this development in negation patterns after the Danish linguist Jespersen. Jespersen observed a negative cycle in several European language (Jespersen 1917:4). It has been shown that, cross-linguistically, there is not only one kind of Jespersen Cycle but several patterns that can be referred to as Jespersen Cycle. For the purpose of this paper, I will not go into details of this corss-linguistic diversity. For further information see van der Auwera (2009) and Vossen (2016).
} 
sources are indefinites, like a word for 'nothing', negative main verbs, like 'refuse' or 'lack', (van Gelderen 2008:196) or negative existentials (Croft 1991:6) that grammaticalize into a negator. Other sources are partitives, like 'a little', nominalizers, possessives or a copy of the original negator (Vossen 2016:36-37).

Jespersen Cycles have been attested in many languages all over the world (van Gelderen 2008; Vossen 2016). According to Vossen (2016:202), Jespersen Cycles are common in the Austronesian language family, especially in those parts of the family which are in contact with Papuan languages. Papuan languages typically have clause-final negation in line with their verb-final word order. This observation suggests that the start of a Jespersen Cycle can be triggered by language contact. An example is provided by Vossen (2016:123). She proposes a Jespersen Cycle in the Austronesian Markham Valley languages in Papua New Guinea. This group of languages has languages in all three stages of a Jespersen Cycle. Some of the Markham Valley languages have pre-predicate single negation, most have double negation and two of them have reached the final stage of post-predicate single negation. The fact that the same pre-predicate negator is shared by languages that have single pre-predicate negation and languages that have double negation is seen as a strong evidence for a Jespersen Cycle. This is also the case for the shared post-predicate negator in varieties that have double and single negation (Vossen 2016:125).

To prove the existence of a Jespersen Cycle, one would, ideally, show the change using historical data of the language under study. However, this can only be done for languages with a long written tradition. Nevertheless, the case study of the Markham Valley languages mentioned above and other recent studies (van der Auwera and Vossen 2016; Vossen and van der Auwera 2014) have shown that it is equally possible to propose a Jespersen Cycle on the ground of synchronic data from several related languages. This article shows that this also is the case for the languages of Flores-Lembata.

To propose a Jespersen Cycle for Flores-Lembata, ideally, all stages of the Jespersen Cycle can be found in this group of languages as well as an overlap of negators between single and double pattern. In the following, I will show that all three of these patterns occur in the Flores-Lembata languages. For the postpredicate negators, we find a shared form between single and double negation patterns. However, for the pre-predicate negators, this cannot be shown clearly. 


\section{Negation patterns in Flores-Lembata languages}

\subsection{Overview of negation patterns}

The varieties of Flores-Lembata listed in the introduction show three types of negation patterns, thus all three stages of a Jespersen Cycle are attested: 1) pre-predicate single negation, 2) embracing double negation and 3) clause-final single negation. These patterns and the varieties showing them are laid out in Table ?? and their geographical distribution is displayed in Figure 3.

\begin{tabular}{lccll}
\hline \multicolumn{2}{c}{ Negation Pattern } & & Variety \\
\hline Pre-predicate: & NEG & $\mathrm{V}$ & & Kedang \\
& & & & Sika \\
Embracing: & NEG & V & NEG & Hewa \\
& & & & LH-Lamalera \\
& & & & LH-Central Lembata \\
Clause-final: & & V NEG & LH-Lewoingu \\
& & & & LH-Lewotobi \\
& & & LH-Solor \\
& & & Alorese \\
\hline
\end{tabular}

Table 2: Negation patterns in Flores-Lembata languages. $\mathrm{NEG}=$ negator, $\mathrm{V}=$ verb, $\mathrm{LH}=$ Lamaholot dialect chain. 


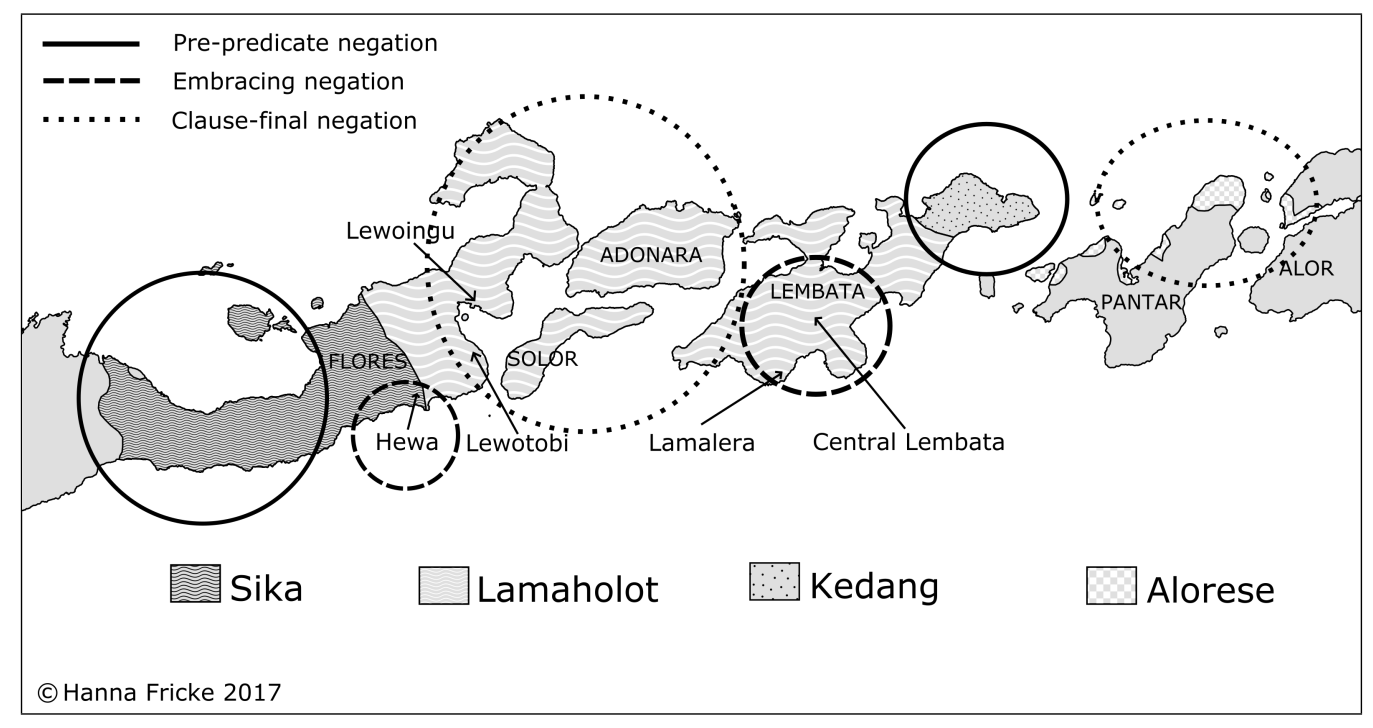

Figure 3: Negation patterns in Flores-Lembata languages.

In Figure 3, it becomes clear that pre-predicate single negation is found in the peripheral varieties of Flores-Lembata, whereas clause-final negation is clustered in the center of the area. In between, there are varieties that show an intermediate state of combining pre-predicate and clause-final negation into an embracing double negation pattern. Alorese in the east diverges from this general distribution. Alorese has clause-final negation, which is otherwise only found in the central area. According to historical and ethnographic sources, the speakers of Alorese most probably emigrated from the Lamaholot area to Pantar around 1.300 AD, and later spread further to Alor (Klamer 2011:16). Taking this historical event into account, the ancestors of the Alorese probably brought clause-final negation with them when moving from the Lamaholot area to Pantar. This is supported by the fact that the Alorese clause-final negator is cognate with the clause-final negators found in the western Lamaholot varieties. The etymology of negators will be discussed further in section 4.

\subsection{Pre-predicate single negation}

Pre-predicate single negation is the main negation pattern in Kedang (1) and in Sika (2). 


\section{(1) Kedang}

Wæi oha? in $=\mathrm{u}$.

water $\mathrm{NEG}$ drink. $1 \mathrm{SG}=1 \mathrm{SG}^{2}$

'I don't drink water.'

(Samely 1991:74)

(2) Sika
A?u ene ra?intan.
1SG NEG know
'I don't know.'

(Arndt 1931:42)

This pattern presents the first stage of a Jespersen Cycle. Interestingly, the second stage, embracing double negation, might be a minor pattern in Sika. Arndt (1931) gives one example of double negation (3), however he does not specify exactly where the data comes from or in which context the sentence appears.

(3) Sika

$$
\begin{aligned}
& \text { Nimu ene leta ata natar pehan e?on. } \\
& \text { 3SG NEG invite person village other NEG } \\
& \text { 'He did not invite the people from the other village.' }
\end{aligned}
$$

(Arndt 1931:42)

In the translation of example (3), Arndt presented the negator in bold, which suggests that the double negation functions as an emphatic negation. If my interpretation of Arndt's bold font as indicating emphasis is correct, it can even be taken as evidence for the first stage of double negation in which this pattern is still emphatic and not yet bleached to become the general pattern.

In the following sections, I show that other Flores-Lembata languages have already reached a stage in which double negation is their general negation pattern.

\subsection{Embracing double negation}

Embracing double negation uses a pre-predicate negator in combination with a clause-final negator. Embracing double negation is the main pattern in Hewa (4), LH-Central Lembata (5) and LH-Lamalera (6).

\footnotetext{
${ }^{2}$ Glosses used in this article: NEG: negator, 1SG: 1st person singular, 3SG: 3rd person singular, 1IN: 1st person inclusive, DIST: distal demonstrative
} 
(4) Hewa

Dedi? anak e?on puas iva.

child little NEG satisfied NEG

'The little child is not satisfied.'

(Fricke 2014:9)

(5) LH-Central Lembata

Ta na modzip si.

NEG 3SG live NEG

'It does not live.'

(Fricke 2016)

(6) LH-Lamalera

T-ai fulâ ${ }^{3}$ pé tana di taku tegel hala. IIN-go market DIST land also NEG see NEG

'When we went to the market, we did not see the island.'

(Keraf 1978:232)

Double negation in Hewa and LH-Central Lembata is not obligatory, either the prepredicate or the clause-final negator can be left out. However, in my corpus data of these varieties, double negation is the most frequent negation pattern used. The data available in Keraf (1978) for LH-Lamalera show consistent double negation as well.

\subsection{Clause-final single negation}

Clause-final single negation is the main negation pattern in Alorese (7) as well as in all known Lamaholot varieties documented outside of the island Lembata. These varieties are LH-Lewotobi (8), LH-Lewoingu (9) and LH-Solor (10).

(7) Alorese

No pana ha nei tahi lahe.

3SG walk this 3SG.go.to sea NEG

'He did not go to the sea.'

(Klamer 2011:87)

\footnotetext{
${ }^{3}$ The vowels with diacritics in this transcription cannot be clearly transferred to IPA (International Phonetic Alphabet). Therefore, the original transcription from Keraf (1978) is kept.
} 
(8) LH-Lewotobi

Go kə̃ ikã hua həla?.

1SG 1SG.eat fish fish.sp NEG

'I don't eat hua fish.'

(Nagaya 2011:392)

(9) LH-Lewoingu

Go bərin na hala?

1SG hit 3SG NEG

'I did not hit him.'

(Nishiyama and Kelen 2007:69)

(10) LH-Solor

Ema dena wata la.

mother cook rice NEG

'Mom is not cooking rice.'

(Kroon 2016:158)

In these LH-varieties, there are remnants of a minor pattern of double negation. Example (11) is taken from a Lamaholot grammar by Arndt (1937). ${ }^{4}$

(11) Lamaholot

Goe gara taka kan? hala.

1SG NEG steal eat NEG

'I did not steal and eat it.'

(Arndt 1937:99)

In example (11), the pre-predicate negator gara is combined with the clause-final negator hala. However, Arndt (1937) notes that this pattern is infrequent. Taking the Jespersen Cycle into account, this infrequent pattern can be seen as evidence that these varieties previously went through a stage of double negation. However, nowadays, this pattern has become infrequent or lost as it is not mentioned in more recent descriptions of these LH-varieties (Kroon 2016; Nagaya 2011; Nishiyama and Kelen 2007).

In sum, this section has shown that all three stages of a negative cycle are found in the languages of the Flores-Lembata area. In the following section, the shape of the negators used in these constructions are discussed.

\footnotetext{
${ }^{4}$ Note that this Lamhaolot grammar excludes Lamaholot varieties on the island of Lembata. Therefore, it does not discuss varieties that have double negation as their main pattern as shown in section 3.3.
} 


\section{Etymology of Flores-Lembata negators}

\subsection{Overview of negators}

Section 4 examines the etymology of pre-predicate and clause-final negators in the Flores-Lembata languages. Knowledge of the negators' origin may shed light on the possibility of a Jespersen Cycle triggered by contact induced change in these languages. Table 3 gives an overview of the negators grouped according to their negation pattern. Only negators appearing in major patterns are discussed.

\begin{tabular}{llrlll}
\hline Negation pattern & Variety & Pre-predicate & & Clause-final \\
\hline \multirow{2}{*}{ Pre-predicate: } & Kedang & oha? & $\ldots$ & \\
& Sika & $e n e$ & $\ldots$ & \\
\hline Embracing: & Hewa & $e$ ?o(n) & $\ldots$ & iva \\
& LH-Central Lembata & $t a / t a k^{5}$ & $\ldots$ & si (ne) \\
& LH-Lamalera & $t a k u$ & $\ldots$ & hala \\
\hline Clause-final: & LH-Lewotobi & & $\ldots$ & hala? \\
& LH-Lewoingu & & $\ldots$ & hala? \\
& LH-Solor & & $\ldots$ & la \\
& Alorese & & $\ldots$ & lahe \\
\hline
\end{tabular}

Table 3: Negators in Flores-Lembata.

In the following sections, I first discuss the etymology of pre-predicate then clausefinal negators as well as their possible origins.

\subsection{Pre-predicate negators}

For the pre-predicate negators, Kedang oha?, Sika ene and Hewa e?o(n), no reconstructed Austronesian proto-form can be found.

For Sika ene and Kedang oha? several possible cognates are found but none of the putative links is strong enough to assume a direct relation of shared inheritance. The Kedang pre-predicate negator oha? could be related to Tetun Fehan's post-verbal negator ha?i (van Klinken 1999:228) and to the Alorese pre-verbal prohibitive haki (Klamer and Kaiping 2017) and Lamaholot's pre-verbal prohibitives

\footnotetext{
${ }^{5}$ The form tak is used for negation of nominals or other non-verbal elements.
} 
ake and eka (Klamer and Kaiping 2017). All these languages are Austronesian languages in eastern Indonesia. However, the origin of the initial /o/ in Kedang oha? would remain unclear.

The Sika negator ene could be cognate with Kedang anuy 'reject, refuse, decline' (Samely 1991:162) or with the Adang post-verbal negator $n \varepsilon n \varepsilon$, a Papuan language of the Timor-Alor-Pantar family (Robinson and Haan 2014). However, these links are equally not strong enough to assume a direct relation.

The putative links for the Sika and Kedang negator to prohibitives or negative verbs in other languages are interesting because these kind of words are cross-linguistically common grammaticalization sources of negators (cf. section 2). However, at this point, it is not possible to make any claim on developments of this kind for Sika and Kedang because the hypothesis that the negators are related to the words given above is merely suggestive.

For the Hewa negator $e ? o(n)$, the homophonous negative existential is a languageinternal source. No cognates of this form in other languages have yet been found. Negative existentials have been shown to be a cross-linguistically common source of verbal negators by Croft (1991). ${ }^{6}$

Among the pre-predicate negators in Table 3, only the negators tak / ta in LH-Central Lembata and taku in LH-Lamalera can be clearly traced back to an Austronesian form. For Proto-Malayo-Polynesian (PMP), which covers all Austronesian languages outside of Taiwan, *ta 'no, not' has been reconstructed as a negative marker (Blust and Trussel 2010b). Reflexes of PMP *ta 'no, not' are found all over Austronesian languages and even, as a result of diffusion, in several non-Austronesian languages (Klamer, Reesink, and van Staden 2008:133, Vossen 2016:161). Therefore, it is assumed that these varieties of Lamaholot retained a reflex of the Malayo-Polynesian negator. The origin of the second part of the pre-predicate negators, $/ \mathrm{k} /$ in LH-Central Lembata and $/ \mathrm{ku} /$ in LH-Lamalera, remains unclear. However, this element is also present in the negative existential take which is a potential source for the verbal negator in LH-Central Lembata and LH-Lamalera.

In sum, the pre-predicate negators found in LH-Lamalera and LH-Central Lembata can be linked to PMP *ta 'no, not', while those of Kedang, Sika and Hewa have diverse, partly unknown, origins.

\footnotetext{
${ }^{6}$ According to Croft's typology of negative existentials and verbal negators, Hewa belongs to Type C where the verbal negator has the same form as the negative existential (Croft 1991:6).
} 


\subsection{Clause-final negators}

Assuming that the ancestral pattern of these languages was to have a pre-predicate negator (cf. discussion in section 5), it is the origin of the clause-final negator that we are most interested in. There are four possibilities to explain the origin of the clause-final negator, a loan, a spontaneous innovation of unknown origin, a prepredicate negator that is copied and used in clause-final position, or an inherited word that became a negator due to grammaticalization. In this section, I show that Lamaholot's clause-final negators are most likely inherited words that grammaticalized, whereas Hewa's clause-final negator is most likely a spontaneous innovation.

For the clause-final negators given in Table 3, three unrelated forms of negators are found, these are Hewa iva, LH-Central Lembata si(ne) and cognates of hala in all other LH-varieties and Alorese.

When looking for cognates of Hewa iva several possibilities come up. 1) The negator iva could be related to $* \mathrm{ba} /{ }^{*} \beta \mathrm{a} /{ }^{*}(\mathrm{u}) \mathrm{wa}$, a cognate set of negators that has been claimed to be of Papuan origin and found all over Austronesian and Papuan languages (Klamer 2004:133, Vossen 2016:158). ${ }^{7}$ 2) The Hewa negator iva could also be related to the pre-predicate negator mbiwa (Antonius and Ruskhan 1997:25) in the Austronesian language Rongga, a variety of Ngadha in middle Flores. 3) Another possible source is the post-predicate particle $f a$ 'a little' in some varieties of Roti, an Austronesian language spoken on the island of Rote close to Timor (Jonker 1908:117). This particle is also used in negations. All these suggestions are difficult to prove because one still has to explain the initial parts of the words and the question remains why cognates are only found in such a limited amount of languages that are geographically far apart. 4) A geographically close source would be the Lamaholot prohibitive nawa found in LH-Lewotobi and LH-Solor, but, again, only the last syllable of the word seems to match. In the absence of stronger evidence, I assume that Hewa's clause-final negator presents a language-internal innovation.

The LH-Central Lembata post-predicate negator si(ne) is homophonous with the LH-Central Lembata word si(ne) 'a little'. It is, thus, hypothesized that si(ne) 'a little' grammaticalized into a negator in LH-Central Lembata. Ultimately, it could be connected to the final syllable of kasi? 'small', which is still found in some LH-varieties (Pampus 1999:197). However, the origin of the optional ulti-

\footnotetext{
${ }^{7}$ The geographically closest non-Austronesian language that has a negator possibly related to this set is the Timor-Alor-Pantar language Western Pantar which has kauwa 'NEG' (cf. Holton 2014:51).
} 
mate syllable /ne/ in the LH-Central Lembata word si(ne) 'a little; NEG' remains unclear. In LH-Central Lembata, final /ne/ is also optionally added to personal pronouns, locationals and demonstratives. It currently appears to be an additional syllable that is used in this language to strengthen short words.

Alorese and all other Lamaholot varieties, except for LH-Central Lembata, have clause-final negators that are cognates of hala and go back to PMP *salaq 'wrong, mistake' (Blust and Trussel 2010a). In the languages concerned, $/ \mathrm{s} /$ to $/ \mathrm{h} /$ is a regular sound change. Apart from this regular sound change, in some varieties, /a/ is weakend to /a/ and final /q/ became / $/$ / or is lost, in LH-Solor the syllable $/ \mathrm{ha} /$ is lost leading to the negator $l a$, and in Alorese, syllable metathesis and vowel rising of /a/ to /e/ word-finally leads to lahe. Most of the varieties discussed also still have a cognate of this word with the original meaning 'mistake'.

In sum, LH-Central Lembata grammaticalized a word for 'a little' into a clausefinal negator, whereas all other LH-varieties and Alorese grammaticalized a word for 'wrong, mistake' into a clause-final negator. On the other hand, the Hewa clause-final negator has to be regarded as an independent innovation for now.

\section{Discussion}

In the previous sections, a Jespersen Cycle in Flores-Lembata has been introduced. Several varieties added a second negator to their pre-predicate negation, gained double negation, and some of them eventually lost the pre-predicate negator and are left with clause-final single negation. Section 4 has shown that the negators used in Flores-Lembata are either inherited Austronesian words or innovations of unknown origin. This counts for the pre-predicate as well as for the clause-final negators.

As mentioned in the introduction, clause-final negation patterns in Austronesian languages have been claimed to be caused by contact with Papuan languages (Reesink 2002:246). This also has been suggested to be the case for Lamaholot in particular (Klamer 2012:76). I this section, I discuss this proposal of contact induced change for Flores-Lembata negation patterns in more detail.

To place the discussion of contact induced clause-final negation in FloresLembata into context, it is important to know that eastern Indonesia is an area characterized by contact between Austronesian and Papuan languages. This contact is not only a recent phenomenon and linguistic features have diffused between languages regardless of their genetic affiliation (Ewing and Klamer 2010; Klamer et al. 2008:10;136). 
Therefore, it is not surprising that clause-final negation is not the only structural feature of Flores-Lembata languages that may point to contact. For Lamaholot in particluar, several features have been suggested to be of non-Austronesian origin (Klamer 2012). These non-Austronesian features include: pre-nominal possessor marking, marking of the distinction between alienable and inalienable possession, post-nominal locative expressions, a focus particle and the absence of a morphological passive voice construction (Klamer 2012:76-86). The fact that there is a whole set of these potential substrate features, strengthens the hypothesis that clause-final negation is also caused by contact.

The strongest evidence for contact-induced grammaticalization leading to a Jespersen Cycle in Flores-Lembata is provided by Vossen (2016)'s typological study on Jespersen Cycles in Austronesian languages. Vossen $(2016: 88,120)$ only finds evidence of double negation and clause-final single negation in areas which are located eastwards to the islands of Borneo and Java. ${ }^{8}$ Further west, no instances of double or clause-final negation are found. This strongly indicates a connection of clause-final negation and the location of Papuan languages.

Thus I consider clause-final negation in Flores-Lembata languages as a case of structural borrowing. Structural borrowing is exactly the kind of trace that would be expected to be left in a situation of langauge shift (Thomason and Kaufman 1988:50). The following elaborates on possible scenarios that could have led to the situation today.

At some point, an ancestor of all Flores-Lembata languages probably had prepredicate single negation. This is because pre-predicate single negation is the most common negation pattern in Austronesian languages (Vossen and van der Auwera 2014:61) and it is also the most common pattern universally (van der Auwera and Du Mon 2015:411). As there are still Flores-Lembata varieties for which prepredicate single negation is the only possible negation pattern (see section 3.2), it is very unlikely that the Jespersen Cycle started in an ancestor language including all the languages of Flores-Lembata. It must have started on a lower level, namely in the ancestors of those languages that now have either double of clause-final negation. This counts for Hewa and all Lamaholot varieties. It is very unlikely that Hewa and Lamaholot had a common ancestor that excluded other varieties of Sika because Hewa is considered to be a variety of Sika (Fricke 2014; Keraf 1978:1,8). It is clearly very closely related to Sika in lexicon and in most features

\footnotetext{
${ }^{8}$ There are two exceptions to this. Chamic and Moken languages, which are Austronesian minority languages in Vietnam, Cambodia and Thailand, show double and post-predicate negation (van der Auwera and Vossen (2015), Vossen (2016:92,117,118)).
} 
of its grammar and less close to Lamaholot. Therefore, Hewa's and Lamaholot's double negation patterns must have arisen independently and cannot be inherited from a common ancestor. How did Lamaholot and Hewa gain their clause-final negators? As these must have been independent processes, I discuss them one by one starting with Lamaholot.

For Lamaholot, one possible scenario is one in which non-AN speakers shifted to Lamaholot, but imposed their native structures on their new language. For this to happen, the speakers must have gone through a long period of bilingualism before finally completely shifting to the new language. From the data available, it cannot be decided if the use of a clause-final negators was initially done to create an emphatic negation or if the clause-final negator directly became part of the general negation pattern. If the clause-final pattern was very salient in the shifting speakers' language representation, it is possible that is was directly copied into the general negation pattern. The origin of the clause-final negators in Lamaholot can be explained by contact-induced grammaticalization (Heine and Kuteva 2003, 2005). Language internal material is used to generate a new grammatical word, a clause-final negator. It remains to be explained why we have two different clause-final negators in the varieties of Lamaholot. LH-Lewotobi, LH-Lewoingu, LH-Solor and LH-Lamalera, all have a cognate of hala going back to PMP *salaq 'wrong'. As LH-Lamalera nowadays still has double negation taku ... hala, combining a reflex of the PMP negator *ta 'no, not' with a grammaticalized word as a second negator, it could be the case that this pattern was initially also present in the other Lamaholot varieties. However, most of them have lost the pre-predicate negator by now. LH-Central Lembata went a slightly different way. LH-Central Lembata does have its own clause-final negator. For the pre-predicate negator, LH-Central Lembata also has a reflex of *ta 'no, not' but the clause-final part of its double negation is si(ne). Probably, several options were competing when clause-final negators were introduced into Lamaholot. Several competing options are also attested for the development of a post-predicate negator in French with point 'point', mie 'crumb' and pas 'step' competing for the clause-final position. In the end one of them, pas, was kept (van der Auwera 2009:44). For Lamaholot, two forms have survived, hala and si(ne).

For Hewa, most likely an independent development occurred. There are two possibilities for the development of the clause-final negator in Hewa. Either the variety also experienced multilingualism by shifting speakers of non-Austronesian languages or it copied the clause-final negation pattern from its neighboring Austronesian language Lamaholot. Hewa is located directly adjacent to LH-Lewotobi. But if this is the case, why would Hewa invent a new word and not copy hola? from 
LH-Lewotobi as Hewa has borrowed other lexical material from Lamaholot? At the current stage, it cannot be decided if there is Papuan substrate in Hewa. For this, other features of the language need to be examined as well.

I have shown that there is evidence to assume contact induced grammaticalization as the cause for clause-final negation in the Lamaholot varieties of FloresLembata. Especially the absence of Jespersen Cycles in Austronesian languages on Borneo, Java and further west and the presence of several potential Papuan features in Lamaholot support the hypothesis that contact induced change led to double and clause-final negation. However, independent innovation as a cause cannot be ruled out completely as no actual borrowed language-material is found. The further examination of other possible contact induced features can shed light on the plausibility of a contact scenario in the Lamaholot-Hewa area. Another question remains open. Why are the Hewa, Sika and Kedang pre-predicate negators so diverse? Why do they show innovations and no reflexes of PMP *ta 'no, not' as varieties of Lamaholot do? While we do not know the answer to these questions, the facts alone at least suggest that Hewa, Sika and Kedang have histories that are quite distinct from the Lamaholot varieties.

In sum, the present varieties of Flores-Lembata provide evidence for all three stages of the Jespersen Cycle. This article has argued that Lamaholot varieties developed negation patterns with clause-final negators due to Papuan influence. For Hewa, this assumption still needs to be examined in further detail. As the copied material is structural and not lexical, language shift preceded by long-term bilingualism of a Papuan speaking population living in the area probably occurred. Speakers of Papuan languages shifted to Lamaholot and introduced a clause-final negator to the language.

\section{Acknowledgments}

This research was supported by the VICI research project 'Reconstructing the past through languages of the present: the Lesser Sunda Islands', funded by the Netherlands Organisation for Scientific Research, project number 277-70-012. I would like to thank Owen Edwards, Marian Klamer, Francesca Moro, Johan van der Auwera, Frens Vossen and two anonymous reviewers for valuable input and comments on earlier drafts of this article. 


\section{References}

Antonius, P., and A. G. Ruskhan. 1997. Struktur bahasa Ngadha dialek Rongga. Jakarta: Pusat Pembinaan dan Pengembangan Bahasa.

Arndt, Paul. 1931. Grammatik der Sika-Sprache. Ende: Arnoldus.

Arndt, Paul. 1937. Grammatik der Solor-Sprache. Ende: Arnoldus.

Blust, Robert, and Stephen Trussel. 2010a. *salaq 'wrong; miss (a target); mistake'. http://www.trussel2.com/acd/acd-s_s1.htm?zoom_highlight=wrong (accessed on 10-03-2017).

Blust, Robert, and Stephen Trussel. 2010b. *ta 'negative marker: No, not'. http://www.trussel2.com/acd/acd-s_t.htm\#30486 (accessed on 15-11-2016).

Croft, William. 1991. The Evolution of Negation. Journal of Linguistics 27:1-27.

Dahl, Östen. 1979. Typology of sentence negation. Linguistics 17:79-106.

Ewing, Michael C., and Margaretha Anna Flora Klamer, ed. 2010. East Nusantara: Typological and areal analyses. Number 618 in Pacific linguistics. Canberra: Pacific Linguistics Australian National University.

Fricke, Hanna. 2014. Topics in the grammar of Hewa: A variety of Sika in Eastern Flores, Indonesia. Munich: Lincom Europe.

Fricke, Hanna. 2016. Corpus of Central Lembata Lamaholot. Leiden University.

Fricke, Hanna. forthcoming. Complex nouns and pronouns in Central Lembata. Wacana: Journal of the Humanities of Indonesia .

van Gelderen, Elly. 2008. Negative cycles. Linguistic Typology 12:195-243.

Heine, Bernd, and Tania Kuteva. 2003. On contact-induced grammaticalization. Studies in Language 27:529-572.

Heine, Bernd, and Tania Kuteva. 2005. Language contact and grammatical change. Cambridge: Cambridge University Press.

Holton, Gary. 2014. Western Pantar. In The Papuan Languages of Timor, Alor and Pantar, ed. Antoinette Schapper, volume 1, 23-95. Berlin: Mouton de Gruyter. 
Jespersen, Otto. 1917. Negation in English and other languages. København: København.

Jonker, J. C. G. 1908. Rottineesch-Hollandsch woordenboek. Leiden: Brill.

Keraf, Gregorius. 1978. Morfologi Dialek Lamalera. Doctoral dissertation, Universitas Indonesia, Jakarta.

Klamer, Marian. 2004. East Nusantara: Genetic, Areal, and Typological Approaches. Oceanic Linguistics 43:240-244.

Klamer, Marian. 2011. A short grammar of Alorese (Austronesian). Munich: Lincom Europe.

Klamer, Marian. 2012. Papuan-Austronesian language contact: Alorese from an areal perspective. In Melanesian languages on the Edge of Asia: Challenges for the 21 th Century, ed. Marian Klamer and Nicholas Evans. Honolulu: University of Hawai'i Press.

Klamer, Marian, ed. 2014. The Alor-Pantar languages: History and typology. Berlin: Language Science Press.

Klamer, Marian, and Gereon Kaiping. 2017. LexiRumah: Lexicon of languages of the Lesser Sunda Islands. http://lessersunda.ullet.net/lexirumah (accessed on 23-3-2017).

Klamer, Marian, Ger Reesink, and Miriam van Staden. 2008. East Nusantara as a linguistic area. In From linguistic areas to areal linguistics, ed. Pieter Muysken, Werner Abraham, and Michael Noonan, number 90 in Studies in language companion series (SLCS), 95-149. Amsterdam: Benjamins.

Kroon, Yosep. 2016. A grammar of Solor Lamaholot: A language of Flores, Eastern Indonesia. Doctoral dissertation, University of Adelaide, Adelaide.

Nagaya, Naonori. 2011. The Lamaholot language of Eastern Indonesia. Doctoral dissertation, Rice University, Houston.

Nishiyama, Kunio, and Herman Kelen. 2007. A grammar of Lamaholot, Eastern Indonesia: The morphology and syntax of the Lewoingu dialect. Munich: Lincom Europe. 
Pampus, Karl-Heinz. 1999. Koda kiwã: Dreisprachiges Wörterbuch der Lamaholot-Sprache, Dialekt von Lewolema. Number LII, 4 in Abhandlungen für die Kunde des Morgenlandes. Stuttgart: Deutsche Morgenländische Gesellschaft Steiner.

Reesink, Ger. 2002. Clause-final negation: Structure and interpretation. Functions of Language 9:239-268.

Robinson, Laura C., and John Haan. 2014. Adang. In The Papuan Languages of Timor, Alor and Pantar, ed. Antoinette Schapper, volume 1, 221-283. Berlin: Mouton de Gruyter.

Samely, Ursula. 1991. Kedang, (Eastern Indonesia), some aspects of its grammar. Number Bd. 46 in Forum phoneticum. Hamburg: H. Buske.

Schapper, Antoinette, ed. 2014. The Papuan Languages of Timor, Alor and Pantar, volume 1. Berlin: Mouton de Gruyter.

Thomason, Sarah, and Terrence Kaufman. 1988. Language contact, creolization, and genetic linguistics. Berkeley: University of California Press.

van der Auwera, Johan. 2009. The Jespersen Cycles. In Cyclical change, ed. Elly van Gelderen, Linguistik aktuell; vol. 146. Amsterdam: Benjamins.

van der Auwera, Johan, and Denies Du Mon. 2015. Negation, Linguistics of. In International Encyclopedia of the Social \& Behavioral Sciences (Second Edition), ed. James D. Wright, 409-414. Oxford: Elsevier.

van der Auwera, Johan, and Frens Vossen. 2015. Negatives between Chamic and Bahnaric. Journal of the Southeast Asian Linguistics Society 8:24-38.

van der Auwera, Johan, and Frens Vossen. 2016. Jespersen cycles in the Mayan, Quechuan and Maipurean languages. In Cyclical change continued, ed. Elly van Gelderen, Linguistics today, volume 227. Amsterdam: Benjamins.

van Klinken, Catherina. 1999. A grammar of the Fehan dialect of Tetun. An Austronesian language of West Timor. Canberra: Pacific Linguistics Australian National University.

Vossen, Frens. 2016. On the typology of the Jespersen Cycles. Doctoral, Universiteit van Antwerpen, Antwerpen. 
Vossen, Frens, and Johan van der Auwera. 2014. The Jespersen Cycles Seen from Austronesian. In The diachrony of negation, ed. Maj-Britt Mosegaard Hansen and Jacqueline Visconti, 47-83. Amsterdam: John Benjamins. 